\title{
ISLAM IN THE EUROPEAN UNION: KEY ISSUES AND DEBATES
}

\section{Dr. Branislav Radeljić}

\begin{abstract}
The founding fathers of the European Union - Konrad Adenauer, Alcide de Gasperi and Robert Schuman - were all Christian Democrats and devoted Catholics. At that time, this aspect was understood as a solid basis for a united Europe and European identity. Since then, however, things have significantly changed as the growing presence of Muslims in the EU has challenged its initially imagined outlook and, accordingly, various issues focusing on Islam, European identity and inclusion of the Muslims continue to penetrate numerous debates and question peaceful coexistence of Muslims and Europeans. While primarily elaborating on the postSeptember 11 dynamics, this paper concludes that coexistence is possible, but only, under certain circumstances.
\end{abstract}

Key words: Islam, EU, Islamophobia, European Identity, Coexistence.

\section{DOES THE PAST MATTER?}

Numerous academic conferences, public talks and informal meetings seek to address the growing presence of Islam in the European Union and, to begin with, many of them question whether the current situation could be better understood if the historical dimension is taken into account. Although the foundations of the then European (Economic) Community and present European Union "are undeniably Christian-Democratic, a capacious political tradition that accommodates temperate offshoots of conservative political Catholicism as well as a social Catholicism," ${ }^{1}$ it is true, as well, that in the 1950s, the presence of Islam in the EU was almost invisible, as rare mosques and occasional gatherings in suburbs of European capitals did not represent a matter worthy of public discussion.

However, in the 1960s, the trend changed rapidly as the economic growth of European countries combined with low birth rates implied that an additional labour force was needed in order to maintain this progress. In this respect, France became a host country for many Muslims from Algeria, Morocco and Tunisia. In his study, Milton Esman explains that the French maintained that most immigrants were not part of their society and that they would probably never become so - an attitude that inspired immigrants' growing attachment to Islam: "They were told by religious leaders, most of whom were trained and imported from their homelands, that religion and government, church and state, cannot, under Islamic law and practice, be separated. Islam, as they preached it, is incompatible with the infidel, amoral, secular cultures of contemporary Europe."

1 Jeffery T. Checkel, and Peter J. Katzenstein, "The Politicization of European Identities," in Jeffrey T. Checkel and Peter J. Katzenstein (eds), European Identity (Cambridge: Cambridge University Press, 2009), 14.

2 Milton J. Esman, Diasporas in the Contemporary World (Cambridge: Polity Press, 2009), 24. 
In West Germany, after the erection of the Berlin Wall, the government signed bilateral agreements with Turkey in 1961, Morocco in 1963 and Tunisia in 1965, all of them permitting the entry of cheap labor. Immigrants gathered at their homes, rather than in public, in order to practice their religious values and this clarifies why the Germans saw immigration "exclusively as working migration in which an ever fluctuating and always renewed population of workers would be involved. The cultural, and thus religious, dimension of immigration was not deemed important enough to warrant any special attention." " Finally, in the United Kingdom, although not a member state of the European Union until 1973, the first large-scale Muslim immigration began in the late 1950s. The Commonwealth Immigration Acts of $1962^{4}$ and $1971^{5}$ did not manage to restrict immigration and, in fact, any new intention to limit it "generated an inflow of migrants in larger numbers, because of the already existing networks of migration - the 'chains' of migration in which seamen and soldiers acted as the first links."

The experience of the above-mentioned European countries shows that both Europeans and Muslims found themselves in a rather unpredictable situation. Throughout this period, Western Europeans, or at least their political authorities, for the sake of economic advancement of their respective countries, ignored the religious denomination of the European Community and its immigrants. More precisely, the religious otherness did not matter as long as the economic benefit was there. In response to the oil crisis in 1973 and the subsequent economic recession, many European governments decided to provide funding to immigrants to return to their homelands, as there was no longer an economic need for them. This policy was not successful and it became clear even then that the ambition to have a Christian European Union was going to face serious challenges.

Aware of this complexity, Europeans insisted on further strengthening of European identity, seeing it often as a powerful tool to address the presence of Islam. The successive waves of immigration and the proliferation of Muslim associations in France and Germany in the 1980s ${ }^{7}$ increased the relevance of Islam to the extent that it became "an agent in the discourse of action or reaction." This performance made a clear division between the two identities, European and Islamic, which was evident in the 1989 headscarf affair in France, when three girls came to their public school wearing headscarves. It served to demonstrate that Islamic identity in the EU was in the process of construction. In her account, Riva Kastoryano looked at the outcome of this event that challenged the relationship between the state, religion and public opinion, and concluded that "[m]obilizations around the headscarf issue have strengthened the leadership of Islamic associations as representatives of a community taking shape around Islam." ${ }^{\prime 9}$

3 Özkan Ezli, "The Development of Turkish Islam in Germany," Internet: http://www.aicgs.org/analysis/c/ezliapr07.aspx, 01/07/2010.

4 “Commonwealth Immigrants Act 1962," Internet: http://www.britishcitizen.info/CIA1962.pdf, 02/07/2010.

5 “Immigration Act 1971," Internet: http://www.britishcitizen.info/IA1971.pdf, 02/07/2010.

6 Konrad Pêdziwiatr, "Muslims in Europe: Demography and Organizations," in Yunas Samad and Kasturi Sen (eds), Islam in the European Union (Oxford, Oxford University Press, 2007), 28.

7 Union des Organisations Islamiques de France, Fédération Nationale des Musulmans de France, Islamrat für die Bundesrepublik Deutchland and Türkisch-Islamische Union der Anstalt für Religion.

8 Riva Kastoryano, "Religion and Incorporation: Islam in France and Germany," International Migration Review, Vol. 38, No. 3, (2004): 1238.

9 Riva Kastoryano, "Religion and Incorporation: Islam in France and Germany," 1240. 
For the advocates favoring the European Union as a Christian-Democratic organization, the collapse of Communism provided a new opportunity for additional support from East Germany, Poland and Czechoslovakia, where the Catholic Church played an important role in overthrowing the regime. With regard to this period, Edward Mortimer talks about two mutually inclusive subjects: Christianity and the Western media. He was quite happy to see "Christianity in vogue" and the Western media to promote it, but, more importantly, he saw media power in a position to deliberately identify "a new threat" to European stability - possibly Islam. ${ }^{10}$ In his view, Europe needed "to define itself in terms ... of Christian heritage, and to emphasize as sharply as possible the distinction and the frontier between itself and the world of Islam."11

Apart from an increasingly evident religious aspect, some other authors identified some new problems. For example, Marcelo Suárez-Orozco talks about important economic and social patterns that could hardly be appreciated in the European Union. For example, he argues that remittances from the immigrants "feed billions of dollars into the peripheries" and "Islamic marriage and divorce patterns and gender relations are disturbing both legally and socially to the host groups." ${ }^{12}$ All these patterns have served to stress the diversity between the Muslims and Christians across the EU and, in fact, have been successful. As Suárez-Orozco concludes, "Islamic culture is perceived by some as not 'quite compatible' with European culture" and it is exactly this perception that began to dominate the discussions about the immigration across the EU. ${ }^{13}$ However, the question of immigration should not be analyzed as exclusively one-directional. Accordingly, here Samuel Huntington, while admitting that "European societies generally do not want to assimilate immigrants or have great difficulty doing so," insists that "the degree to which Muslim immigrants and their children want to be assimilated is unclear." ${ }^{\text {"Th }}$ This statement is justified, regardless of Huntington's hardly acceptable intention to demonize Islam. Since its foundation, the EU has been an attractive immigration destination. Even if, at various points, some of its member states wished to see immigrants go back to their country of origin, this did not happen. On one hand, while disappointed by the immigrants' decision to remain, the EU developed a standpoint that was often interpreted as a policy of marginalization or exclusion. On the other hand, the immigrants often wanted to see the process of assimilation conducted under their own terms and conditions, such as keeping dual citizenship illegally or rejecting European values while enjoying European benefits. However, where most academic and non-academic accounts agree is that the terrorist attacks of September 11, 2001, encouraged reconsideration of every possible aspect of Islam and its presence in the West or, more relevantly for us here, in the European Union.

\section{CURRENT DEBATES}

Ibrahim Kalin's account of the Euro-American perception of the September 11 attacks maintains that the whole event was "interpreted as the fulfillment of a prophecy that had been in the consciousness of the West for a long time, i.e., the coming of Islam as a menacing power with a

${ }^{10}$ Edward Mortimer, “Christianity and Islam," International Affairs, Vol. 67, No. 1, (1991):10.

11 Ibid.,13.

12 Marcelo M Suárez-Orozco, "Migration, Minority Status and Education: European Dilemmas and Responses in the 1990s," Anthropology \& Education Quarterly, Vol. 22, No. 2, (1991):101.

13 Ibid., 103.

${ }^{14}$ Samuel P.Huntington, The Clash of Civilizations and the Remaking of World Order (New York: Free Press, 2002), 204. 
clear intent to destroy Western civilization." 15 The Western media and policy-makers often presented Islam as a potential threat to non-Muslim countries. The result, as warned by Michael Humphrey, has been the following:

Contemporary Muslim experience in the West has contributed to the emergence of a globalized Islam, a de-culturalized and de-territorialized neo-fundamentalist 'pure-Islam.' Diaspora Islam has been transformed by the experience of marginalization and the loss of social authority of their cultures and religion. But the way public safety wars have targeted Islam/Muslims as a potential source of dangerous global circulation has had the consequence of locking them into an endless symbiotic relationship because the former can never guarantee security, it can never control the dangerous global circulation of risks. ${ }^{16}$

In order to show the relevance of the above noted issues, I identify various topics that have dominated debates about Islam in the European Union. First, as already envisaged, Islam is presented as a threat to security. In 2003, EU officials adopted the European Security Strategy, which identified terrorism and Islamic political radicalism as key threats, although without making any reference to religion. ${ }^{17}$ However, the ideas in this document were primarily discussed among the EU officials, while the public consciousness was shaped by the media that talked about Muslims as potential terrorists, extremists and radicals. Some of them tried to justify the threatening aspect of Islam by looking into the future. For example, The Daily Telegraph accused the British government and the rest of the EU of "ignoring a demographic time bomb ... including millions of Muslims [who] will change the continent beyond recognition over the next two decades." ${ }^{18}$ These words surely question the work performed by the EU policy-makers. Indeed, apart from their initial engagement with the European Security Strategy and, to the lesser extent, the European Neighborhood Policy, Brussels officials have not offered any substantially improved document in regard to Muslim presence in the EU.

The main reason behind the European attitude is that it had already committed itself to the Muslim community by deciding to accept Turkey as a candidate country for EU membership during the Helsinki Summit of $1999 .{ }^{19}$ The summit confirmed the EU's readiness to support diversity within its own borders, thereby contradicting the original perception of the European polity as exclusively Christian-Democratic. In addition, acceptance of the Turkish candidacy encouraged greater expression of the Muslim network across the EU. In her study, Kastoryano examined the supporting role of international organizations interested in Islam in Europe and noted that these organizations "mobilize resources to allow Muslims to go beyond the national diversity in the various countries of the European Union and to create a single religious identification and a

15 Ibrahim Kalin, "Roots of Misconception: Euro-American Perceptions of Islam Before and After September 11," in Joseph E. B. Lumbard (ed), Islam, Fundamentalism, and the Betrayal of Tradition (Bloomington, IN: World Wisdom, 2009), 149

${ }^{16}$ Michael Humphrey, "From Diaspora Islam to Globalised Islam," in Shahram Akbarzadeh and Fethi Mansouri (eds), Islam and Political Violence (London: IB Tauris, 2010), 123.

${ }^{17}$ Council, "European Security Strategy: A Secure Europe in a Better World," Internet: http://www.consilium.europa.eu/uedocs/cmsUpload/78367.pdf, 06/07/2010.

18 Adrian Michaels, "Muslim Europe: the Demographic Time Bomb Transforming our Continent," The Daily Telegraph, 8 August 2009.

19 Helsinki European Council, "Presidency Conclusions, 10 and 11 December 1999," Internet: http://www.europarl.europa.eu/summits/hel1_en.htm, 05/07/2010. 
transnational solidarity based on this diversity. ${ }^{20}$ By saying so, it appears that Europeans have had a problem with Islamic unity and, moreover, due to their own incapacity to achieve greater European unity, perceive Muslims as a threat.

The second topic about the Muslims in the European Union, although continuously used to justify the first one, concentrates on the conflicting nature of Islam. Here, both the Western media and the public have unintentionally promoted what is Huntington's understanding of the relations between Islam and Christianity. While seeing them as "stormy," he noted that "[t]he $20^{\text {th }}$ century conflict between liberal democracy and Marxist-Leninism is only a fleeting and superficial historical phenomenon compared to the continuing and deeply conflictual relation between Islam and Christianity." ${ }^{, 1}$ The complexity of this relationship is further confirmed by the fact that some Islamic states, such as Turkey and Iran, took part in the wars in Bosnia-Herzegovina and Kosovo by openly protecting and supporting the local Muslims against the local Christians. However, this transnational involvement is important as it contributes to the previously mentioned points about the construction of a unifying identity among all the Muslims. Thus, regardless of their country of origin, their collective interest transcends boundaries, ignores diversity among their homelands and, most relevantly, leads to Islam's representation and recognition within the society.

Finally, the third topic focuses on what I call visual otherness. The 1989 headscarf affair in France indicated that Muslim fashion is perceived differently across the European Union. For example, the Courrier International reported that not all EU member states reacted in the same way: "In France, the classroom is the ideal place to transmit lay, republican values. Every girl who dares to wear her headscarf in class thus risks sparking a national scandal. In Germany, little girls are left in peace". ${ }^{22}$ However, it did not take long for the Germans to reconsider their approach. In September 2003, the constitutional court ruled: "While the state of Baden-Württemberg had no grounds to ban ... an Afghan-born teacher from wearing a headscarf in school, it was free to enact legislation to this effect. ${ }^{, 23}$ Understandably, the debates about the Muslim outfit in France and Germany spread among the rest of the EU.

What we as the public get to know about Islam often depends on the media's decision on what to offer us. In his 1997 book, Edward Said explored Western media coverage of Islam and listed a number of relevant consequences that usually followed:

One is that a specific picture - for it is that - of Islam has been supplied. Another is that its meaning or message has on the whole continued to be circumscribed and stereotyped. A third is that a confrontational political situation has been created, pitting 'us' against 'Islam.' A fourth is that this reductive image of Islam has had ascertainable results in the world of Islam itself. A fifth is that both the media's Islam and the cultural attitude to it can tell us a great deal not only about 'Islam' but about institutions in the culture, the politics of information and knowledge, and national policy. ${ }^{24}$

Each of Said's five points finds a place in current, post-September 11 debates about Islam in the EU. For example, his notion of a specific picture of Islam could relate both to its visual expression

${ }^{20}$ Riva Kastoryano, op. cit., 1251.

${ }^{21}$ Samuel P Huntington,, op. cit., 209.

22 "France Sees Headscarves as a Veiled Threat," Courrier International, 29 September 2003.

${ }^{23}$ Bertrand Benoit, "Do any other European States Feel the Same Way?," Financial Times, 4 November 2003.

${ }^{24}$ Edward W. Said,, Covering Islam (London: Vintage Books, 1997), 44. 
through habits and outfits or general perception of Islam as a threat. While Muslims do not have a problem with praying in the middle of their Western-style shopping malls, Westerners find it strange or, even, intimidating. While the majority of Muslim women choose to wear burqas, Europeans often feel sorry for them. Over time, being different and being seen as a potential threat have reinforced stereotyping about Islam and further division between 'us' and 'Islam' or viceversa. If not minimized, this division could affect any coexistence negatively. In addition, a reductive image of Islam has opened questions about Muslim identity and as a result has led to its greater expression. Finally, Said is right when noting the power of the media in presenting Islam and shaping public opinion.

Indeed, the media face no obstacles in their intention to approach the public. For example, in relation to Islam and terrorism, one scholar analyzes the rapid development and power of the media and underlines that "the more recent forms of terrorism are aimed not at specific and limited enemy objectives but at world opinion. Their primary purpose is not to defeat or even weaken the enemy militarily but to gain publicity and to inspire fear - a psychological victory." ${ }^{25}$ This is exactly what consolidates the concept of Islamophobia. In its 1997 report, the Runnymede Trust, a well-known non-governmental organization, published eight points that are related to the concept of Islamophobia. ${ }^{26}$ In short, these points indicated that there was a serious problem with the perception and acceptance of Islam. These points warned that an obvious presence of Islamophobia could widen the gap between the EU and its Muslim communities. Nonetheless, Islamophobia became a matter of serious discussions only after the terrorist attacks against the USA and subsequent attacks in Madrid and London, in 2004 and 2005. Following these attacks, the Council of Europe presented its definition of Islamophobia as "the fear of or prejudicial viewpoint towards Islam, Muslims and matters pertaining to them. Whether it takes the shape of daily forms of racism and discrimination or more violent forms, Islamophobia is a violation of human rights and a threat to social cohesion" ${ }^{27}$ Thus, although less broad, the post-September 11 definition is relevant for two reasons in particular: first, it linked Islamophobia to violations of human rights and, second, it underlined the linkage between Islam and social cohesion.

A question of who is to blame for Islamophobia has two answers. The first answer sees the Western media as an unbeatable force to 'promote' Islamophobia. Indeed, following the events of September 11, "certain specific and often predictable [media] sources have been actively incorporating the most explicit expressions of Islamophobia into their coverage deeming their actions irresponsible, prejudicial, inciteful and more directly, extremely dangerous." ${ }^{28}$ Thus, while

${ }^{25}$ Bernard Lewis, The Crisis of Islam (London: Orion Books, 2004), 125.

${ }^{26}$ These points are: "1. Islam is seen as a monolithic bloc, static and unresponsive to change; 2 . Islam is seen as separate and 'other.' It does not have values in common with other cultures, is not affected by them and does not influence them; 3. Islam is seen as inferior to the West. It is seen as barbaric, irrational, primitive, and sexist; 4. Islam is seen as violent, aggressive, threatening, supportive of terrorism, and engaged in a clash of civilizations; 5. Islam is seen as a political ideology, used for political or military advantage; 6. Criticisms made of 'the West' by Islam are rejected out of hand; 7. Hostility towards Islam is used to justify discriminatory practices towards Muslims and exclusion of Muslims from mainstream society; 8. Anti-Muslim hostility is seen as natural and normal" (Islamophobia: A Challenge for Us All," quoted in European Monitoring Centre on Racism and Xenophobia, "Muslims in the European Union: Discrimination and Islamophobia," 61; Internet: http://fra.europa.eu/fraWebsite/attachments/Manifestations_EN.pdf, 09/07/2010).

${ }^{27}$ Ingrid Ramberg, Islamophobia and Its Consequences on Young People (Strasbourg: Council of Europe, 2005), 6.

${ }^{28}$ Christopher Allen, "Islamophobia in the Media since September 11," paper presented at the University of Westminster, School of Law, (London, 29 September 2001), 3. 
it is not difficult to agree with this observation and many similar ones that accompanied the attacks in the US and Europe, Islamophobia has primarily been understood as a Western prejudice against Islam and rejection of everything that has something to do with it.

The second answer sees Muslim communities as responsible for Islamophobia themselves. Various terrorist groups have decided to provide the media with video footage explaining their intentions and goals. By deciding to do this, they have provoked greater Islamophobia in the West. Understandably, the public will always react to these sorts of statements. After conducting a survey about Muslims, the EU summarized the findings:

On average 1 in 3 Muslim respondents were discriminated against in the past 12 months, and $11 \%$ experienced a racist crime. The highest levels of discrimination occurred in employment ... thousands of cases of discrimination and racist crime remain invisible ... People without citizenship and those who have lived in the country for the shortest period of time are less likely to report discrimination. Regarding the reasons for not reporting incidents, 59\% of Muslim respondents believe that 'nothing would happen or change by reporting' ... Ethnicity is the main reason for discrimination ... Only $10 \%$ stated that they thought the discrimination they experienced was based solely on their religion. ${ }^{29}$

The above figures are important not only because they show that being Muslim in the EU can be rather difficult, but because they question some of the aspects of the Union it has boasted about, such as the respect for diversity and inclusion. Discriminatory policies in employment lead to a conclusion that the EU is not as open as it claims itself to be. Ethnic background and dress often have primacy over educational background and professional expertise. More alarming is the fact that many Muslims believe that reporting discrimination seems pointless. Such a belief implies that the European leaders who deal with these highly sensitive issues maintain dual standards, shifting from favoring diversity and inclusion to ignoring them, depending on occasion.

In his 2009 book, Christopher Caldwell questions whether Europe can be the same with different people in it. He argues that the initial idea of a united Europe did not take immigration into consideration: in the 1950s and 1960s, "European tolerance of other cultures was sincere, particularly among elites, but not even they anticipated that such tolerance would mean the establishment, entrenchment, and steady spread of a foreign religion on European soil." ${ }^{, 30}$ Indeed, for a long time, Europeans were busy with their ever expanding European project, primarily inspired by economic cooperation and progress, whereas any religious aspect of the Community was ignored. As noted earlier, Muslims were allowed to come to Europe based on various bilateral agreements, but as soon as their help was not needed, the host countries across Europe expected them to leave. Although this did not happen, Caldwell notes that even "when Islam became Europe's main religious problem, almost nobody dared to say so." ${ }^{\text {31 }}$

However, the European Union opted for a strategy that is nowadays criticized for trying to bring two rather contrasting dimensions together. The first dimension is all about the European ambition to see the EU as united in its diversity. In this respect, European elites call for greater inclusion of the Europeans coming from new member states as well as existing non-Europeans in the EU.

${ }^{29}$ European Union Agency for Fundamental Rights, "Data in Focus Report: Muslims," 8; Internet: http://fra.europa.eu/fraWebsite/attachments/EU-MIDIS_MUSLIMS_EN.pdf, 09/07/2010.

${ }^{30}$ Christopher Caldwell, Reflections on the Revolution in Europe (London: Penguin Books, 2009), 91.

${ }^{31}$ Ibid., 161. 
What remains unclear is whether the elites do so for the sake of their own self-promotion in the EU and highly attractive benefits or they really want to see a diverse EU. For example, while there is an evident interest in Turkish EU membership, both sides perceive it as a complex puzzle that still lacks many of its pieces.

The second dimension is about the European ambition to push for a greater European identity as many Europeans have realized that both integration and progress of the European Union will depend on the existence of a strong European identity. While not having offered any clear idea regarding Muslims living across the EU and their role in the whole process, the strengthening of a European identity could not be interpreted as a European intention to combat Islam, but to integrate it under certain, - its own - conditions. Accordingly, numerous additional questions have emerged relating to the mechanisms of the EU to address Muslims within its borders and the power of Islam to affect or even dismantle the whole concept of a European identity or, even more, the EU. These still require answers.

\section{FORTHCOMING DILEMMAS}

Discussions about the future take numbers seriously. For example, France, Germany and the United Kingdom together have more than ten million Muslims and more than 6000 mosques. ${ }^{32}$ The number of Muslims in the European Union is likely to increase. The officials in Brussels claim to be committed to the non-EU countries that have already been granted candidate status or wish to apply and eventually become full EU member states. This means that if Turkey, BosniaHerzegovina, Albania and Kosovo become members of the EU, its Muslim population will amount for over 100 million. But are the Brussels decision-makers ready to face a more obvious presence of Islam in the EU? In his analysis, Caldwell shows that the importance of Islam in Muslim communities in Europe is on the rise: "In France, 85 percent of Muslim students describe their religious beliefs as 'very important,' versus 35 percent of non-Muslims. In Germany, too, religiosity is more widespread among Muslim immigrants than among natives -81 percent of Turks come from a religious background, versus 23 percent of Germans. ${ }^{, 33}$ These percentages are likely to be even higher with more Muslims in the EU.

However, the lack of well-defined policies to address Islam in the EU equals an emergence of new challenges. For example, the accession of Turkey to the EU would be a good test to understand the relationship between the Union and Islam. In his study, Erik Zürcher correctly argues that Turkey's accession to the EU "would confront the Union with a state whose historical development has left it with ties between religion and the state that go further than those of any other member" - an aspect that would surely change in the long term due to the unavoidable democratization process characterized by greater religious plurality. ${ }^{34}$ Indeed, Brussels officials are aware of the existing differences between the two parties. In 2005, one of the reports revealed:

Perhaps the most sensitive of all arguments centers on cultural and religious differences. Since the EU identifies itself as a cultural and religious mosaic that recognizes and respects diversity, supporters of Turkey's EU bid believe that, as long as both Turkey and the EU member states maintain this common vision, cultural and religious differences should be irrelevant. The EU

${ }^{32}$ Statistics offered by European Commission's Eurostat and Network of European Foundations.

${ }^{33}$ Christopher Caldwell, op. cit., 143.

${ }^{34}$ Erik J. Zürcher, The European Union, Turkey and Islam (Amsterdam: Amsterdam University Press, 2004), 54. 
member states' concerns over Turkey's human rights record as well as global and regional security-related issues have also been key factors behind Turkey's prolonged application process. ${ }^{35}$

Although optimistic about the EU-Turkey cooperation, this statement warns about complexities accompanying Turkey's path towards the EU. Still, if cultural and religious differences are given priority, the extent to which both parties are ready to compromise is worthy of consideration. While both the EU and Turkey are proud of their cultures, religious beliefs and prejudices, it will be difficult to abandon these as substantially irrelevant. Moreover, it is the EU which has insisted on greater European identity as a valid counter objection to Islamic identity within the Union. Finally, different understandings about human rights may be conflicting, as both sides have longestablished records in this field. ${ }^{36}$

With regard to the other, above-mentioned potential EU member states, the situation in BosniaHerzegovina, to take the first example, is rather unstable. ${ }^{37}$ The religious composition of the country has always mattered and in the case of any new conflict, the parties involved could easily ask for and receive support from countries with a shared religious belief. This was already the case in the past and there is no reason to doubt its repetition. In fact, the period following the end of the war and division of Bosnia-Herzegovina in 1995 has been characterized by further accentuation of religious differences among the country's constituent peoples. Alongside this, Tone Bringa noted a dual relevance of Islam for Bosnian Muslims: first, it brings and binds them closer together as opposed to Serbian or Croatian, thus Orthodox or Catholic and, second, it connects them to Muslims worldwide as opposed to non-Muslims. ${ }^{38}$ This notion is important in relation to the accession of Bosnia-Herzegovina to the EU. Apart from being perceived as a tool to improve the overall economic and political performance of the county, it is questionable whether EU membership would manage to bring Bosnian peoples together or if Muslims would prioritize the establishment of greater links with other Muslim communities in the EU, thus supporting greater Islamic identity.

In predominantly Muslim Albania, Islam has gained a fuller relevance since the collapse of Communism. Contrary to expectations, American and, more importantly, European investment did not materialize instantly - an important aspect that inspired the slogan "Towards Europe or Islam." In her study, Miranda Vickers summarized the outcome: "In the months that followed [the fall of Communism] an Arab-Albanian Islamic Bank was established in Tirana and around 20 Arab Islamic foundations were opened throughout the country. Foreign Islamic organizations began a country-wide mosque construction program and even funded the expenses of those Albanians wishing to travel to Mecca for the annual Hajj pilgrimage." 39 However, two decades after, it is difficult to believe that strong connections already established between Albania and some Arab countries will be fully ignored when discussing the accession of Albania to the EU. In

\footnotetext{
35 "EU-Turkey Relations," Internet: http://www.euractiv.com/en/enlargement/eu-turkey-relations/article-129678, 26/07/2010.

${ }^{36}$ For an analysis of human rights, see, for example, Arikan, Harun, Turkey and the EU: An Awkward Candidate for EU Membership?, (Hampshire, Ashgate, 2006), 111-157.

${ }^{37}$ Bosnia-Herzegovina is the sixtieth and the only European country listed in "The 2010 Failed States Index" of the 60 most troubled countries in the world (Foreign Policy, July/August 2010, 76).

38 Tone Bringa, Being Muslim the Bosnian Way (Princeton. NJ: Princeton University Press, 1995), 197.

39 Miranda Vickers, Islam in Albania (Shrivenham, Defence Academy of the United Kingdom, 2008), 2.
} 
fact, as observed by Vickers, "[s]ome Albanians believe that one reason Europe appears to be in no rush to embrace Albania as a member of the European Union, is that the majority of the population come from a Muslim background." ${ }^{40}$

Finally, in Kosovo, a country that has faced numerous problems regarding its international recognition, Islam has been one of the most important dividing characteristics between the Serbs and the Kosovo Albanians, thus Christians and Muslims. However, some EU member states, such as France, Germany and the United Kingdom, although having openly claimed to have occasional problems with their own Muslims, never abandoned the Muslims in Kosovo in their fight for independence. Brussels officials seem to have ignored the religious aspect of Kosovo and the idea that an independent Kosovo will possibly create greater links with Muslims across the EU and further undermine the efforts surrounding European identity. Again, here double standards seem to penetrate some significant decisions related primarily to the present EU policy-making and the future European identity. In fact, the case of Kosovo can easily be interpreted as the EU's readiness to reconsider its project about a European identity or even abandon it.

One scholar examines the state of affairs across the European Union and notes that "the accession of Muslim countries and the rise of far-right mobilization and violence can only be addressed effectively under a broad consensus among its members. Across Europe, however, the citizens are split regarding its cultural identity and social model. ${ }^{, 41}$ This split is even more accentuated by the fact that immigration and the Islamization of immigrants in the EU is regulated by the individual member states, not the Union. Accordingly, extreme differences between Germany and the Netherlands in relation to the legal status of Islam represent an additional challenge to the idea about European identity. ${ }^{42}$ Furthermore, a reconsideration of the European identity will imply a reconsideration of Western values. In this respect, Zürcher has a valid point when saying: "The many Muslims in the EU member states also mean that European identity and civilization can no longer be defined in purely Western terms." ${ }^{43}$

The present European Union struggles with tolerance. According to Michael Ignatieff,

[t]he essential task in teaching 'toleration' is to help people see themselves as individuals, and then to see others as such - that is, to make problematic that unthought, unconsidered fusion of personal and group identity on which racism depends. For racism and intolerance are, at a conceptual level, procedures of abstraction in which actual, real individuals in all their specificity are depersonalized and turned into ciphers or carriers of hated group characteristics. $^{44}$

If looking closer at the concept of European tolerance, "with its philosophical foundations and political aims, [it] was the result of persistent efforts by different and quarrelling peoples who

40 Ibid., 5.

41 Juan Díez Medrano, “The Public Sphere and the European Union's Political Identity,” in Jeffrey T. Checkel and Peter J. Katzenstein (eds), European Identity (Cambridge: Cambridge University Press, 2009), 106.

42 In Germany, the state and religious institutions are not separated; while the Jewish community, the Catholic Church and the Protestant Church are all recognized by the state, Islam is not. In the Netherlands, the state and religious institutions are separated; the Dutch system allows all religions to establish their own institutions, including Islam.

43 Erik J. Zürcher, op. cit., 74.

44 Michael Ignatieff, "Nationalism and the Narcissism of Minor Differences," in Ronald Beiner (ed), Theorizing Nationalism (Albany, NY: SUNY Press, 1999), 101. 
basically were not tolerant at all." ${ }^{45}$ For example, with regard to Muslims, apart from seeing the burqa as a symbol for "the repression that women can suffer in Islam" and a threat to "security, sexual equality and secularism," some European governments would like to see it banned although "banning it altogether would be an infringement on the individual rights which their culture normally struggles to protect." ${ }^{, 46}$ Out of 5 million Muslims in France, only about 2000 cover their face fully. This micro-minority was enough for the National Assembly to pass a draft law on 13 July 2010 stating that "no one can, in the public space, wear clothing intended to hide the face." By becoming law, the ban is expected to apply both to the residents and visitors in France and offenders will face penalties, fines or prison. ${ }^{48}$ Thus, while the French leaders justify the ban as the right way to fight all forms of religious extremism, they cannot predict possible reactions. Indeed, if talking about consequences of the ban, the most dangerous aspect seems overlooked: the French leadership has ignored the fact that the decision to ban burqas "may stigmatize Islam and create a defensive reaction" across the EU. ${ }^{49}$

\section{CONCLUSION}

The presence of Islam in the European Union represents a growing concern both for the Muslims and the Europeans who, while having to understand that the days when the Union was exclusively Christian are gone, will have to integrate their Muslim communities. In this respect, I addressed some of the present issues and debates. In the future, new enlargements of the EU will bring more Muslims into the Union. Accordingly, policy-making should focus on the process of inclusion and less on the ideas to strengthen European identity that, intentionally or not, could lead to exclusion or to the emergence of an ever stronger Islamic identity across the EU. The media and the public are aware of the complexity of the subject and are ready to discuss the future. Indeed, while some contributions manage to inspire further Islamophobia by questioning whether Europe will become "a new 'Eurabia',",50 others try to transmit what many European Muslims see as the cosmopolitan nature of Islam and its readiness to coexist with the others. ${ }^{51}$ But under what conditions?

45 Evyatar Friesel, The Days and the Seasons (Detroit, MI, Wayne State University Press, 1996),102.

46 "A Bad Idea," The Economist, 15 May 2010, 18.

47 Quoted in Bobby Ghosh, “The Moment,” Time, 26 July 2010, 7.

${ }_{48}$ David Gauthier-Villars, "France Advances Ban on Some Islamic Veils," The Wall Street Journal, 14 (July 2010), A15.

49 "Running for Cover," The Economist, Internet: http://www.economist.com/node/16113091/print, 26/07/2010.

${ }^{50}$ For example, one discussant noted: "What will Europe be like in 20 or 30 years we simply cannot know for sure. The dominant cultures may rise up in reaction to an increasing Islamization of their population. One thing for sure, look for some major cultural conflicts in the future. Will Europe quietly pass into the night and increasingly transition into a new 'Eurabia'? Maybe. I am praying and hoping for a Christian revival to spread across the face of Europe once more and bring thousands of Muslims to Christ - that too would bring a major change to Europe and beyond" ("The Islamization of Europe," Internet: http://answersforthefaith.com/2009/08/08/the-islamization-of-europe/, 10/07/2010).

${ }^{51}$ As Maisami put it: "Islam's future depends upon its ability to wed Western-style modernism with Islamic principles, or, in other words, whether it can develop an Islamic-style modernism. The challenge is to engage in modernity without sacrificing Muslim values or undermining Islamic principles. 'As we are only slowly realizing, Islam is truly a world religion, increasingly visible in Europe and the United States as well as Asia, Africa, and the Middle East.' It is significant for the future of Islam that "the capitals and major cities of Islam are not only Cairo, Istanbul, Mecca, but equally Paris, London, New York”" (M. Maisami, "Islam and Globalization,” The Fountain, Summer 2003). 


\section{SELECTED BIBLIOGRAPHY}

1. Allen, Christopher. "Islamophobia in the Media since September 11," paper presented at the University of Westminster, School of Law. London, 29 September 2001.

2. Benoit, Bertrand."Do any other European States Feel the Same Way?," In Financial Times, 4 November 2003.

3. Bringa, Tone. Being Muslim the Bosnian Way. Princeton. NJ: Princeton University Press, 1995.

4. Caldwell,Christopher. Reflections on the Revolution in Europe. London: Penguin Books, 2009.

5. Checkel, Jeffery T. and Peter J. Katzenstein, "The Politicization of European Identities." In Jeffrey T. Checkel and Peter J. Katzenstein (eds), European Identity. Cambridge: Cambridge University Press, 2009.

6. Esman, Milton J. Diasporas in the Contemporary World. Cambridge: Polity Press, 2009.

7. Friesel, Evyatar.The Days and the Seasons. Detroit, MI, Wayne State University Press, 1996.

8. Gauthier-Villars, David. "France Advances Ban on Some Islamic Veils," The Wall Street Journal, 14 (July 2010), A15.

9. Humphrey, Michael"From Diaspora Islam to Globalised Islam." In ShahramAkbarzadeh and FethiMansouri (eds), Islam and Political Violence. London: IBTauris, 2010.

10. Huntington, Samuel P. The Clash of Civilizations and the Remaking of World Order. New York: Free Press, 2002.

11. Ignatieff, Michael. "Nationalism and the Narcissism of Minor Differences." In Ronald Beiner (ed), Theorizing Nationalism. Albany, NY: SUNY Press, 1999.

12. Kalin, Ibrahim."Roots of Misconception: Euro-American Perceptions of Islam Before and After September 11." In Joseph E. B. Lumbard (ed), Islam, Fundamentalism, and the Betrayal of Tradition. Bloomington, IN: World Wisdom, 2009.

13. Kastoryano, Riva. "Religion and Incorporation: Islam in France and Germany," International Migration Review, Vol. 38, No. 3, (2004): 1238.

14. Lewis,Bernard.The Crisis of Islam. London: Orion Books, 2004.

15. Medrano,Juan Díez. “The Public Sphere and the European Union's Political Identity.” In Jeffrey T. Checkel and Peter J. Katzenstein (eds), European Identity. Cambridge: Cambridge University Press, 2009.

16. Michaels, Adrian. "Muslim Europe: the Demographic Time Bomb Transforming our Continent." In The Daily Telegraph, 8 August 2009.

17. Mortimer, Edward "Christianity and Islam." In International Affairs, Vol. 67, No. 1, (1991) 
18. Pêdziwiatr, Konrad. "Muslims in Europe: Demography and Organizations." In YunasSamad and KasturiSen (eds), Islam in the European Union. Oxford, Oxford University Press, 2007.

19. Ramberg, Ingrid. Islamophobia and Its Consequences on Young People. Strasbourg: Council of Europe, 2005.

20. Said, Edward W.Covering Islam. London: Vintage Books, 1997.

21. Suárez-Orozco, Marcelo M, "Migration, Minority Status and Education: European Dilemmas and Responses in the 1990s." In Anthropology \& Education Quarterly, Vol. 22, No. 2, (1991):101.

22. Vickers,Miranda. Islam in Albania. Shrivenham, Defence Academy of the United Kingdom, 2008.

23. Zürcher, Erik J. The European Union, Turkey and Islam. Amsterdam: Amsterdam University Press, 2004. 